\title{
Report on the SALEX '97 Lexicographical Training Course, Grahamstown, 15-27 September 1997
}

\author{
Penny Silva, Dictionary Unit for South African English, \\ Grahamstown, South Africa
}

\begin{abstract}
The report describes the background to the SALEX '97 Lexicographical Training Course, and the reasons for its conception. It explains the constraints within which the course had to be designed, and lists its practical and theoretical aims. The financing of the course, the range of participants attending, the structure of the working day, and the course materials provided to participants are described. The report ends with excerpts from evaluations provided by participants, and with a reference to the second planned training course, SALEX '98. The simple initial framework upon which the course was based is provided as an Appendix.
\end{abstract}

Keywords: SOUTH AFRICA, LEXICOGRAPHY, TRAINING, SALEX, CORPUS, AFRICAN LANGUAGES, LANGUAGE-INDEPENDENT, PROJECT PLANNING, DICTIONARY COMPILATION

Opsomming: Verslag oor die SALEX '97 leksikografiese opleidingskursus, Grahamstad, 15-27 September 1997. In hierdie verslag word die agtergrond waarteen die SALEX '97 leksikografiese opleidingskursus plaasgevind het, geskets en daar word redes aangevoer vir die ontstaan daarvan. Die beperkings waarbinne die kursus ontwerp moes word, word beskryf en die praktiese en teoretiese doelwitte van die kursus word gelys. Die finansiering van die kursus, die verskeidenheid kursusgangers, die uiteensetting van die werksdag en die kursusmateriaal wat aan die kursusgangers verskaf is, word uiteengesit. Hierdie verslag eindig met aanhalings uit kursusgangers se evaluerings van die kursus, asook met 'n verwysing na die tweede beplande kursus, SALEX '98. Die eenvoudige aanvanklike raamwerk waarop die kursus gebaseer is, word as 'n Bylae weergegee.

Sleutelwoorde: SUID-AFRIKA, LEKSIKOGRAFIE, OPLEIDING, SALEX, KORPUS, AFRIKATALE, TAALONAFHANKLIK, PROJEKBEPLANNING, WOORDEBOEKSAMESTELLING

\section{Background}

The impetus for the SALEX '97 Lexicographical Training Course came from the South African postapartheid constitution, under which nine African languages were added to English and Afrikaans as official languages. State-funded units for the compilation of dictionaries exist at present for only English and Afrikaans, but there are moves afoot to right this imbalance. The National Dictionary Units Bill has been under consideration for over a year, and it was hoped 
that several Units might have been established by the time the course was presented. However, establishment was unfortunately delayed because the Bill was withdrawn for reconsideration.

The success of the new Units, when they are established, will depend upon the development of a cadre of lexicographers with the practical and intellectual skills to tackle every aspect of running a dictionary project. Conceived in order to help prepare lexicographers, particularly in the African languages, for this task, SALEX '97 ("South African Lexicography") was organized by Penny Silva, Director of the Dictionary Unit for South African English at Rhodes University, under the auspices of the Department of Arts, Culture, Science and Technology, and of the African Association for Lexicography (AFRILEX).

The course was led by three eminent British lexicographers and teachers Sue Atkins (course leader), Michael Rundell, and Edmund Weiner. Their enthusiasm for contributing to the training of lexicographers for the new South African society, their extensive theoretical knowledge, and their collective experience at the practical end of lexicography made them ideal leaders of the training course. Their expertise covers bilingual, pedagogical, and scholarly dictionaries, and includes corpus development and the design of systems for corpus querying, and for the electronic compilation and manipulation of dictionary text, as well as the training of lexicographers in both research and commercial institutions.

SALEX '97 took place in the St. Peter's Building, Rhodes University, Grahamstown, during the second half of September, 1997.

\section{Financing the Course}

The course received substantial support from donors, making the project possible, and helping to keep the cost to the participants within manageable limits. The two major donors were the British Council and the national Department of Arts, Culture, Science and Technology, and generous funding was also provided by the Anglo American and De Beers Chairman's Fund, and First National Bank. Sets of forty learners' dictionaries were donated by Addison Wesley Longman, Cambridge University Press, and HarperCollins (all in the United Kingdom), and Oxford University Press (Southern Africa). Xeratech provided free photocopying of much of the course material. Expenses were considerable, but were partly offset by the R500 registration fee paid by most of the participants. Several participants requested assistance: in these cases the registration fee was waived, and for two participants additional financial support was provided (accommodation and/or travel costs being covered).

\section{The Participants}

The thirty-five SALEX '97 participants were representative of all of the eleven official languages with the exception of Xitsonga. Some languages (e.g. Sepedi, 
isiZulu, isiXhosa, Afrikaans, and English) were well-represented, with three or more participants each. The participants were drawn from universities, provincial and national language and terminology departments, dictionary units, publishers, and the international Summer Institute of Linguistics. Two participants were freelancers. In all, fifteen languages were represented. In addition to the South African participants, there were several lexicographers working in other African languages - Chiluba (Zaire), Mwani (Mozambique), Kiswahili (Tanzania), and Amharic/Silte (Ethiopia) - as well as participants from neighbouring African countries (Lesotho and Swaziland). Two participants came from Europe.

Mr John Orr of the SABC attended part of the course as an observer, and recorded interviews for a series of three programmes for SAfm's Word of Mouth language programme, broadcast during October 1997.

\section{The Course: Theory and Preparation}

In September 1996, the organizer sent a list of the various components of dictionary compilation to Sue Atkins for her consideration. The final version of this list (see Appendix) formed the framework upon which the course was based. The course aimed to enable participants to

- plan a dictionary project;

- design a dictionary appropriate to the needs of their language community;

- build and train a team of lexicographers; and

- edit their dictionary to publication stage.

The challenge while planning and designing the course was to make sure that it was

- a general, broad, basic training in dictionary-making, including projectplanning;

- situated firmly within the empirical and descriptive tradition;

- language-independent, applicable to many different languages;

- English-medium, using English examples, but at a level which would be accessible to all;

- of a content level which would suit participants with differing levels of experience;

- practically oriented, not simply theoretical; and

- exhaustively documented, providing participants with a comprehensive record of proceedings for subsequent use.

The result was a course which is believed to be a first in world lexicography an intensive methodological foundation-course which is language-independent. The course had four main strands: 
- the practical business of planning a dictionary project and taking the editorial process through to completion;

the metalexicographic concepts needed for discussing the structure and editorial content of dictionaries (macrostructure and microstructure);

the concepts from linguistic theory that can usefully inform and underpin aspects of the lexicographer's work, particularly when analysing the data and drafting the entry; and dictionary entry writing.

The organiser and three trainers met in Lewes, East Sussex, in February 1997 for a two-day planning meeting, during which the South African language and lexicographical background was discussed, the course outline designed, the programme plotted out, and the lecturing tasks allocated. For the next six months, extensive four-way discussion took place on email, and electronic files containing slide-presentations and worksheets were sent to Grahamstown as attachments to email letters. Designing and planning such a course jointly without electronic communication would not have been possible.

\section{The Course: Organization}

SALEX '97 ran for ten working days, from 9h00 until 16h30, with an hour for lunch and two 20-minute tea-breaks daily. The working language was English. Each half-day module consisted of a lecture (with overhead slides and identical handout material) and a practical workshop (with worksheets). There were also plenary sessions, including demonstrations of corpus software.

Groups were initially mixed, in order to ensure that the participants talked across linguistic boundaries, but participants subsequently worked mainly in four language-groups: English, Afrikaans, Nguni, and Sotho. The trainers moved from one group to the next, offering assistance and comment. Participants worked extremely hard, and with great enthusiasm and dedication - something the trainers all remarked upon.

The course took participants from the first stages of project planning and the identification of their target user, through the collection and analysis of data, and the compilation of entries, to choices in publishing their dictionaries. Most of the time was spent on analysis of data (using a large computer-based corpus of English, loaned by Addison Wesley Longman UK) and on entry-compilation for a general user's dictionary, but there was time given also to specialized skills such as etymology and pronunciation.

During the lectures, the participants were able to follow the overhead slides on an identical printed version, and could thus add their own notes as the course progressed. At the end of the course, each participant possessed a large file of material which could be used for training their colleagues - a file containing close to 800 overheads, dozens of worksheets, a bibliography, a 22page glossary of terms used during SALEX ' 97 , and a list of contact names and addresses of all attending the course. 


\section{Evaluation}

SALEX '97 exceeded the organizer's expectations in the quality of its content and teaching, the response of the participants, and the spirit of common purpose which developed. The degree of commitment from both trainers and participants was impressive.

The course was highly intensive for trainers and participants alike (and particularly for participants for whom English was not first language), leading the trainers to question whether any modules could have been dropped. In the end, consensus was that little if any of the course should have been omitted, given that participants had extensive documentation to take away with them. With this documentation, participants should be able to recap on the course, run local training programmes, and spend more time on workshop exercises, as required.

The following responses are excerpts from evaluation-forms completed by participants after SALEX '97:

The theoretical background gained from the course will enhance the quality of our dictionary's results and output. A follow-up course is a dire necessity. SALEX should investigate the possibility of formulating a structured course in lexicography registered at any South African university for purposes of improving the lexicographer's qualifications.

Since I already have a finished manuscript, I am now able to revisit it methodically and with confidence. My experience before and after this conference should make me a better trainer of young lexicographers. Not only did we learn about dictionary-making as such, our lecturers virtually took us on a guided tour around our own brains to help us observe just how language is computed. It was an unforgettable experience.

More than ever before I am now aware of the complexities of dictionary compilation, as well as the thrill of actually realizing that I am (and have been) making progress. The sooner we have another course concentrating on the lexicographical problems peculiar to the South African indigenous languages, the better.

SALEX was an historic event ... All role-players or potential role-players in the lexicography industry were able to learn for two weeks from the knowledge of the presenters. They were also able to learn from one another, discovering new points of contact between the various languages, etc. Presenting a training course for such a divergent group makes great demands on the presenters. They succeeded to a high degree in being "everything for everyone" ... A follow-up course is imperative, because a process was initiated which should not be allowed to die. Certain needs of the participants were identified, and it is imperative 
that attention be given to these, in order to get the dictionary-making industry in African languages established effectively.

Reservations expressed by some participants were

- that there was too much covered in the time available;

- that some course modules were not directly relevant to the types of dictionaries being planned by individuals or groups; and

- that bilingual dictionary-making should have been covered.

There was a strong conviction expressed that further linked training courses were essential.

\section{The Future}

SALEX ' 97 was the first of three practical courses planned by AFRILEX for South African lexicographers - the initial grounding in general methodology and practice. The second course, SALEX '98, will apply the SALEX '97 principles to bilingual dictionary-making, and will consider the specific problems of the African languages (two areas of great concern which arose out of SALEX '97). The course will be organized by Professor Daan Prinsloo at the University of Pretoria in September 1998.

\section{Further information can be obtained from:}

Daan Prinsloo: PRINSLOO@libarts.up.ac.za

Penny Silva: P.Silva@ru.ac.za

Website: URL: http://www.ru.ac.za/affiliates/dsae/salex97 


\section{APPENDIX}

\section{The components of dictionary production}

A. COLLECTING DATA

1. Choosing data: corpus design
a. Types of data
b. Types of corpus

2. Gathering and storing data: corpus maintenance
a. Print corpus
b. Electronic corpus

3. Accessing the data

B. PLANNING A DICTIONARY

1. What kind of dictionary? (i.e. dictionary macrostructure)

2. Dictionary type? (i.e. who is the user?)

3. The word-list

4. The entries

5. Supporting material

C. WRITING A DICTIONARY

1. Analysing the data

2. Compiling an entry

D. TEXT PRODUCTION 